\title{
Diversity of the Ant Genus Neoponera Emery, 1901 (Formicidae: Ponerinae) in the North of the Brazilian Atlantic Forest, with New Records of Occurrence
}

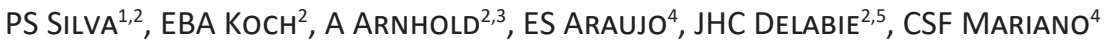 \\ 1 - Graduate Program in Ecology and Biodiversity Conservation, Santa Cruz State University (UESC), Ilhéus, Bahia, Brazil \\ 2 - Laboratory of Myrmecology, Cocoa Research Center, CEPLAC, Itabuna, Bahia, Brazil \\ 3 - Federal University of Southern Bahia (UFSB), Training Center in Agroforestry Sciences, CEPLAC, Ilhéus, Bahia, Brazil \\ 4 - Laboratory of Social Arthropods DCB/UESC, Ilhéus, Bahia, Brazil \\ 5 - DCAA/UESC, Ilhéus, Bahia, Brazil
}

\section{Article History}

\section{Edited by}

Gilberto M. M. Santos, UEFS, Brazil

Received 06 March 2020

Initial acceptance 15 April 2020

Final acceptance 23 June 2020

Publication date 30 September 2020

\section{Keywords}

Geographic distribution, species richness, forest fragmentation, forest formations, vegetation types, Doce River.

\section{Corresponding author}

Priscila Santos Silva

Laboratory of Myrmecology

Cocoa Research Center - CEPEC/CEPLAC

Caixa Postal 7, CEP: 45.600-970

Itabuna, Bahia, Brasil.

E-Mail: priscilapitth@hotmail.com

\begin{abstract}
Composed of two main forest formations, Ombrophilous Forest and Seasonal Forest, the Brazilian Atlantic Forest biome is constituted currently by a mosaic of forest remnants and secondary vegetation. Representatives of the Ponerinae ant genus Neoponera are observed mainly in both wet and seasonally dry forests. The aim of this study was to approach the diversity of the genus Neoponera in the north of the Atlantic Forest of Brazil (from the extreme north of its distribution to the Doce River hydrographic basin in the south), associating the occurrence of ant species with the types of vegetation. We have compiled occurrence data from the collection of the Myrmecology Laboratory of the Cocoa Research Center, on internet, or available in literature. We found information on 23 species of Neoponera, including a new record for the Atlantic Forest, Neoponera globularia (Mackay \& Mackay, 2010), and a new record for Brazil, Neoponera fiebrigi Forel, 1912. The relative composition of the Neoponera assemblages was evaluated according to the types of vegetation. We found that the occurrence of the genus Neoponera is mainly related to the types of vegetation of the focus region, principally dense forests where a higher diversity was observed.
\end{abstract}

\section{Introduction}

The Brazilian Atlantic Forest is considered a global conservation hotspot (Myers, 2000; Mittermeier et al., 2005), as it is one of the richest biomes in biodiversity as well as one of the most threatened on the planet, since only $12.4 \%$ of forest remnants remain compared to the original coverage of 1,315,460 $\mathrm{km}^{2}$ in the 16th Century (SOS Mata Atlântica, 2018; INPE, 2018). With this significant reduction of its original coverage, the current landscape of the Atlantic Forest is composed by a mosaic of native vegetation fragments and crop areas, including forest remnants of over 3 hectares of different shapes and sizes, of these two main forest formations:
Ombrophilous Forest and Seasonal Forest (Ribeiro et al., 2009; Tabarelli et al., 2010; SOS Mata Atlântica, 2018; INPE, 2018; MMA, 2018). In perennial ombrophilous forests, the incidence of sunlight is low at the lower strata and the trees are tall; on the other hand, in semideciduous or deciduous seasonal forests, a considerable part of the foliage is lost during the dry season, which favors the penetration of sunlight until the floor, contributing to the formation of a more open vegetation structure with few epiphytes (Pereira, 2009; Colombo \& Joly, 2010).

Studies on the structure and composition of animal and plant communities are essential for the recovery and preservation of forest remnants (Ferreira et al., 2018), as well as for the conservation of biological diversity. However, we 
must understand first the main patterns of their geographic distribution to carry out these studies (Papes \& Gaubert, 2007; Sigrist \& Carvalho, 2008). In view of their high diversity and sensitivity to changes in the physical and biological environment, the insects, especially the ants (Hymenoptera: Formicidae), are useful for such studies (Santos et al., 2006; Ribas et al., 2012; Schmidt et al., 2013). Some ants directly or indirectly control the availability of resources, changing the state of biotic or abiotic conditions for other organisms (Jones et al., 1997). Their role as ecosystem engineers, coupled with their abundance in terrestrial ecosystems, reveals the ecological importance of this group (Folgarait, 1998). These ants contribute to structure the environment through soil ventilation and nutrient cycling, seed dispersal, mutualistic associations with plants and animals, on evolutionary as well as ecological scales (Moreau et al., 2006; Klimes et al., 2012; Dejean et al., 2014).

Ponerinae is one of the most diverse groups within Formicidae with regard to morphology and behavior. In this subfamily, Neoponera is the second more genus in the Neotropical Region (after Leptogenys) with 57 species (Mackay \& Mackay, 2010; Schmidt \& Shattuck, 2014), occurring from southern Texas and northern Mexico to northern Argentina and southern Brazil (Mackay \& Mackay, 2010). To date, 35 species of Neoponera have been recorded in Brazil (Feitosa, 2015), with representatives found throughout the country, preferably in humid forests, at ground level or in trees, but also in dry forests with seasonal rainfall (Lattke, 2003; 2015).

Ants of the genus Neoponera generally are much more frequent in conserved areas than in anthropized lands (Campiolo et al., 2015). This fact strongly suggests that a set of information on the distribution of this group can help in monitoring environment quality and, furthermore, will provide valuable arguments to justify policies aiming at the implantation of conservation units. Although the pattern of global ant diversity is similar to that of other taxa (for example, vascular plants), many regions have much less recorded diversity than expected. This can be related to several factors, including climate change and migration, emphasizing that regions with still unknown diversity are often the regions where deforestation is occurring most rapidly (Guénard et al., 2012), such like the Atlantic Forest. The present study aimed to analyze the current diversity for the Neoponera genus in the northern part of the Brazilian Atlantic Forest biome, inserting new records, evaluating the richness and the association of Neoponera species with different forest formations (types of vegetation) within the biome.

\section{Material and methods}

Study area

The Atlantic Forest covers an area of approximately $1,110,182 \mathrm{~km}^{2}$ (IBGE, 2004a), being composed of the two main formations: coastal forest (perennials ombrophilous forests) and tropical seasonal forest (Morellato \& Haddad, 2000), subdivided into different vegetation types according to the classification of the Brazilian Institute of Geography and Statistics (IBGE) (Fig 1/Table1), such as the: Pioneer Formation Areas under Marine and Fluvial Influence (Pf), Pioneer Formation under Marine Influence (Pm), Pioneer Formations with Agricultural Activities (AA.P), Savannah/Seasonal Forest with Agricultural Activities (AA.SN), Savannah/Ombrophilous Forest with Agricultural Activities (AA.SO), Dense Ombrophilous Forest of Lowlands (Db), Savannah/Ombrophilous Forest (SO), Open Ombrophilous Vegetation - Secondary Vegetation and Agrarian Activities (VS-AA.A), Seasonal Deciduous Forest - Secondary Vegetation and Agrarian Activities (VSAA.C), Dense Ombrophilous Forest - Secondary Vegetation and Agrarian Activities (VS-AA.D) and Semideciduous Seasonal Forest (Secondary Vegetation and Agrarian Activities) (VS.AA.F). In addition to associated ecosystems such as mangroves, sea shore vegetation, highland fields, inland swamps and forest entrances in the Northeast, housing thousands of species of plants and animals (Ribeiro et al., 2009; Tabarelli et al., 2010; SOS Mata Atlântica, 2018; MMA, 2018).

We defined the Doce River as the southern geographic boundary to outline the studied area, which is the northern part of the Brazilian Atlantic Forest (Fig 1). The Doce River

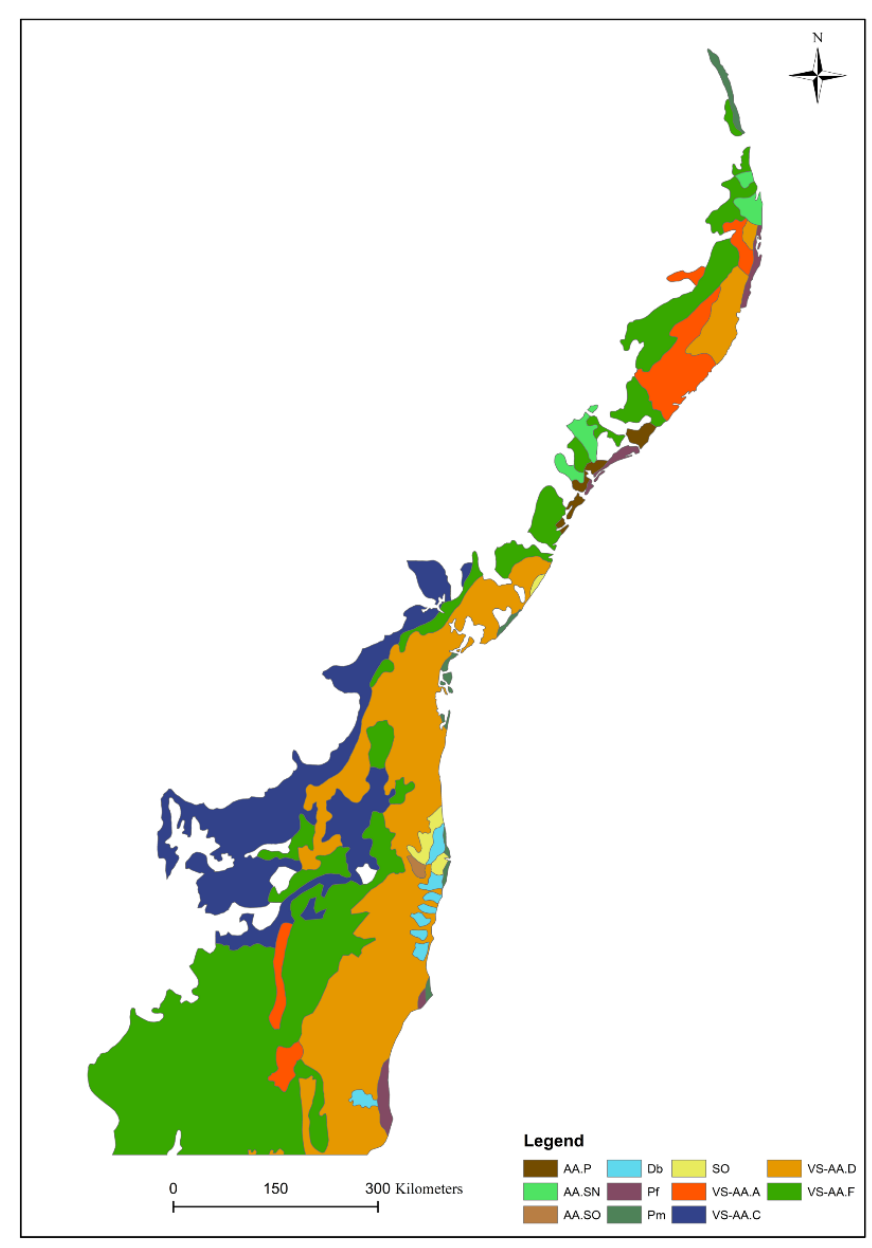

Fig 1. Map of the study area. 
is one of the larger Brazilian rivers and its hydrographic basin presents a worrying picture of environmental degradation, since it is within the limits of two global biodiversity hotspots, 98\% of its area is in the Atlantic Forest and the remaining 2\% in the Cerrado (Mittermeier et al., 2005; Azevedo-Santos et al., 2016; Pires et al., 2017). The Doce River flows $888 \mathrm{~km}$ and its basin has an area of about $84,000 \mathrm{~km}^{2}$, of which $86 \%$ are in the state of Minas Gerais and 14\% in that of Espírito Santo. It is considered as an effective biogeographical barrier at least since the Pleistocene (Carnaval \& Moritz, 2008). Thus, the analyzed area covers from the Southeast of Brazil, from the north of Espírito Santo and part of Minas Gerais, to the Northeast of the country, and includes the states of Bahia, Sergipe, Alagoas, Pernambuco, Paraíba and Rio Grande do Norte. In the Northeast, the biome is limited to the Caatinga and in the Southeast, to the Cerrado (Pereira, 2009). In general, it presents precipitation index above $1,000 \mathrm{~mm}^{3}$ per year and several climatic types, such as humid tropical, hot and super humid, tropical altitudinal and mesothermal climates according to the Köppen-Geiger classification (Pereira, 2009).

\section{Data collection}

Neoponera species data were set up from the Myrmecology Laboratory collection of the Cocoa Research Center (CPDC), at Ilhéus-BA, Brazil, looking for information on specimen collection locations and geographic coordinates. Occurrence data were also compiled from the online data networks Antweb.org (accessed on 2018/2019) and Antmaps. org (accessed on 2018/2019). Another search was performed based on literature, using the species names as keywords. We consider the possibility that the species was registered with an outdated name, especially when included in the genus Pachychondyla before the revision of this genus by Schmidt and Shattuck (2014). We reviewed information about these species across Brazil and, subsequently, analyze their distribution in the north of the Brazilian Atlantic Forest biome to compile the list of species and data (reference codes are available in Table 5).

\section{Statistical analysis}

We built a spreadsheet with data compiled for the occurrence of species recorded in different locations in the north of the Atlantic Forest biome. We assessed the structure of Neoponera assemblages according to the types of vegetation (Table 1; Fig 1). For that purpose, we evaluated the similarity of Neoponera assemblages (species presence/absence) according the vegetation types using the Jaccard's index. In addition, the association between species and vegetation types was illustrated using a multidimensional non-metric ordering (NMDS) using the Bray-Curtis index. These analyzes were performed using the software R v. 3.6.1(R Development Core Team 2019).
Table 1. Description and classification of vegetation types currently found in the Atlantic Forest in the studied region, Brazil.

\begin{tabular}{|c|c|}
\hline Description of classified vegetation & $\begin{array}{l}\text { Classification } \\
\text { legend }\end{array}$ \\
\hline $\begin{array}{l}\text { Pioneer Formations under Marine and Fluvial } \\
\text { Influence }\end{array}$ & Pf \\
\hline Pioneer Formations under Marine Influence & $\mathrm{Pm}$ \\
\hline Pioneer Formations with Agriculture & AA.P \\
\hline Savanna/Seasonal Forest with Agriculture & AA.SN \\
\hline Savanna/Ombrophilous Forest with Agriculture & AA.SO \\
\hline Dense Ombrophilous Forest of Lowlands & $\mathrm{Db}$ \\
\hline Savanna/Ombrophilous Forest & $\mathrm{SO}$ \\
\hline $\begin{array}{l}\text { Open Ombrophilous Vegetation (Secondary } \\
\text { Vegetation and Agriculture) }\end{array}$ & VS-AA.A \\
\hline $\begin{array}{l}\text { Seasonal Deciduous Forest (Secondary } \\
\text { Vegetation and Agriculture) }\end{array}$ & VS-AA.C \\
\hline $\begin{array}{l}\text { Dense Ombrophilous Forest (Secondary } \\
\text { Vegetation and Agriculture) }\end{array}$ & VS-AA.D \\
\hline $\begin{array}{l}\text { Semideciduous Seasonal Forest (Secondary } \\
\text { Vegetation and Agriculture) }\end{array}$ & VS-AA.F \\
\hline
\end{tabular}

Source: Vegetation map of Brazil (IBGE, 2004b available online at http:// www.ibge. gov.br).

\section{Results}

The total number of records of the survey comprises 23 species (Table 2) of Neoponera, distributed in the Atlantic Forest above the geographical boundary of Doce River (Tables 3 and 4). Between these, Neoponera globularia (Mackay \& Mackay, 2010) is a new record for the Atlantic Forest, and Neoponera fiebrigi Forel, 1912 a new record for Brazil. We also found records of Neoponera goeldii Forel, 1912 (species previously known from the Amazonian biome only) in the state of Bahia at least at 1,500 km further east from the nearest record.

The species recorded in the higher number of vegetation types (Table 2) were Neoponera apicalis (Latreille, 1802) (recorded in seven vegetation types, 63.6\%), Neoponera villosa (Fabricius, 1804) and Neoponera curvinodis (Forel, 1899) (five vegetation types, $45.4 \%$ each). Among the other species, seven were recorded in a single type of vegetation. The species with the highest number of occurrences by type of vegetation were $N$. apicalis (48 records), Neoponera concava (Mackay \& Mackay, 2010) (52), Neoponera bucki (Borgmeier, 1927) (18), and Neoponera inversa (Smith, 1858) (14), all for the vegetation VS-AA.D (Table 2).

The types of vegetation that presented a higher number of species of Neoponera were: VS-AA.D (19 spp.), VS-AA.C (10) VS-AA.F (7) and SO (6). The number of species in the other types of vegetation varied from one to three (Fig 2). Three vegetation types presented only a single species: VSAA.A and $\mathrm{Db}$ (N. apicalis) and AA-SN (N. villosa) (Fig 2). 
Table 2. List of Neoponera species recorded in different vegetation types in the Brazilian Atlantic Forest biome. The values represent the number of records.

\begin{tabular}{|c|c|c|c|c|c|c|c|c|c|c|c|}
\hline \multirow{2}{*}{ Species } & \multicolumn{11}{|c|}{ Vegetation types } \\
\hline & AA.P & AA.SN & AA.SO & Db & Pf & $\mathbf{P m}$ & So & VS-AA.A & VS-AA.C & VS-AA.D & VS-AA.F \\
\hline Neoponera apicalis (Latreille, 1802) & & & 1 & 1 & & & 1 & 1 & 2 & 38 & 4 \\
\hline $\begin{array}{l}\text { Neoponera bactronica (Fernandes, } \\
\text { De Oliveira \& Delabie, 2014) }\end{array}$ & & & & & 1 & & & & 1 & 5 & \\
\hline Neoponera bucki (Borgmeier, 1927) & & & & & & & 1 & & & 16 & 1 \\
\hline Neoponera carinulata (Roger, 1861) & & & & & & 1 & & & & 4 & \\
\hline Neoponera cavinodis Mann, 1916 & & & & & & & & & 1 & 1 & \\
\hline $\begin{array}{l}\text { Neoponera concava (Mackay, W.P. } \\
\& \text { Mackay, E.E., 2010) }\end{array}$ & & & & & & & 5 & & & 42 & 5 \\
\hline Neoponera crenata (Roger, 1861) & & & & & & & & & & 1 & 2 \\
\hline Neoponera curvinodis (Forel, 1899) & 1 & & & & 1 & & & & 2 & 2 & 3 \\
\hline Neoponera fiebrigi Forel, 1912 & & & & & & & & & 2 & & \\
\hline $\begin{array}{l}\text { Neoponera globularia (Mackay, W.P. } \\
\& \text { Mackay, E.E., 2010) }\end{array}$ & & & & & & & & & & 2 & \\
\hline Neoponera goeldii Forel, 1912 & & & & & & & & & & 1 & \\
\hline Neoponera inversa (Smith, F., 1858) & & & & & & 2 & 3 & & & 9 & \\
\hline Neoponera laevigata (Smith, F., 1858) & & & & & & & & & & 2 & \\
\hline Neoponera magnifica (Borgmeier, 1929) & & & & & & & 1 & & 1 & 1 & \\
\hline Neoponera marginata (Roger, 1861) & & & & & & & & & 1 & & \\
\hline Neoponera moesta Mayr, 1870 & & & & & & & & & 2 & & \\
\hline Neoponera obscuricornis (Emery, 1890) & & & 1 & & & & & & & & \\
\hline $\begin{array}{l}\text { Neoponera schultzi (Mackay, W.P. \& } \\
\text { Mackay, E.E., 2010) }\end{array}$ & & & & & & & & & & 3 & \\
\hline Neoponera striatinodis Emery, 1890 & & & & & & & & & & 1 & 1 \\
\hline Neoponera unidentata Mayr, 1862 & & & 1 & & & & 1 & & 2 & 4 & \\
\hline Neoponera venusta Forel, 1912 & & & & & & & & & & 3 & \\
\hline Neoponera verenae (Forel, 1922) & 1 & & & & & & & & & 5 & \\
\hline Neoponera villosa (Fabricius, 1804) & & 1 & & & & 1 & & & 2 & 4 & 1 \\
\hline
\end{tabular}

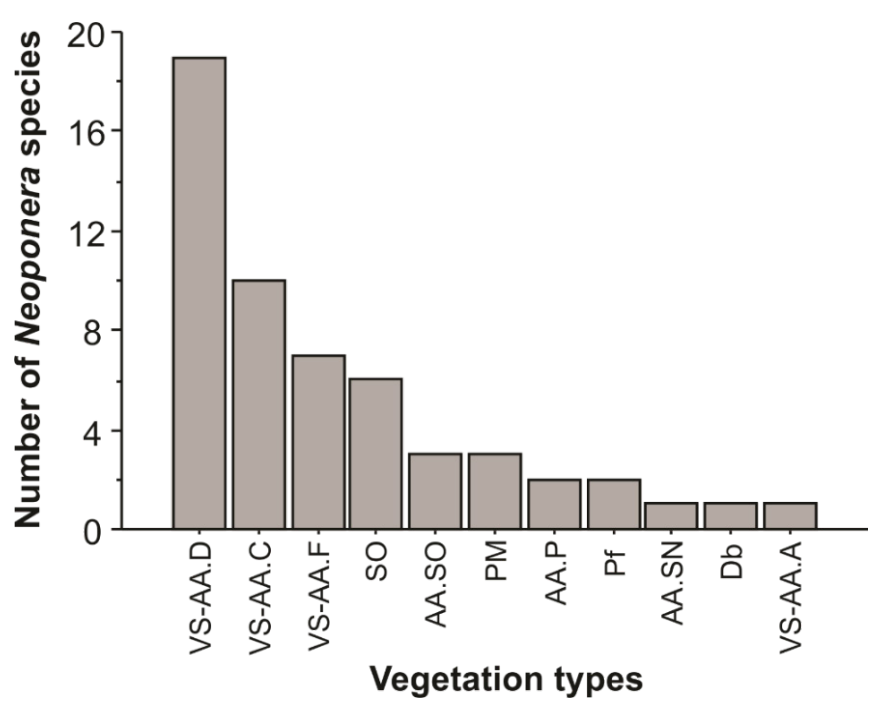

Fig 2. Neoponera diversity according to types of vegetation of the Brazilian Atlantic Forest biome. The codes on the $\mathrm{X}$ axis correspond to the types of vegetation listed in Table 1 .
When we test the similarity between vegetation types according to the presence/absence of Neoponera species, we observed that $\mathrm{Db}$ and VS-AA.A share the same assemblages (Fig 3). In general, the other types of vegetation present low similarity between them (less than 50\%), especially VSAA.D and VS-AA.C (about $40 \%$ of similarity). It is worth noting that the assemblages found in vegetation types Pf and AA.P (38\% similarity between them) have low similarity with the other vegetation types (Fig 3).

The relative superposition of certain vegetation types with some Neoponera is observed on NMDS graph (Fig 4). The grouping with the species found in the same vegetation types is evident, such as $N$. globularia, $N$. goeldii, Neoponera laevigata (Smith, 1858), Neoponera schultzi (Mackay \& Mackay, 2010), Neoponera venusta Forel, 1912 occurring in VS-AA.D. The same occurs for N. fiebrigi, Neoponera marginata (Roger, 1861) and Neoponera moesta (Mayr, 1870) in VS-AA.C, as well as for Neoponera carinulata (Roger, 1861) in Pm. The greatest distance was observed for Neoponera 


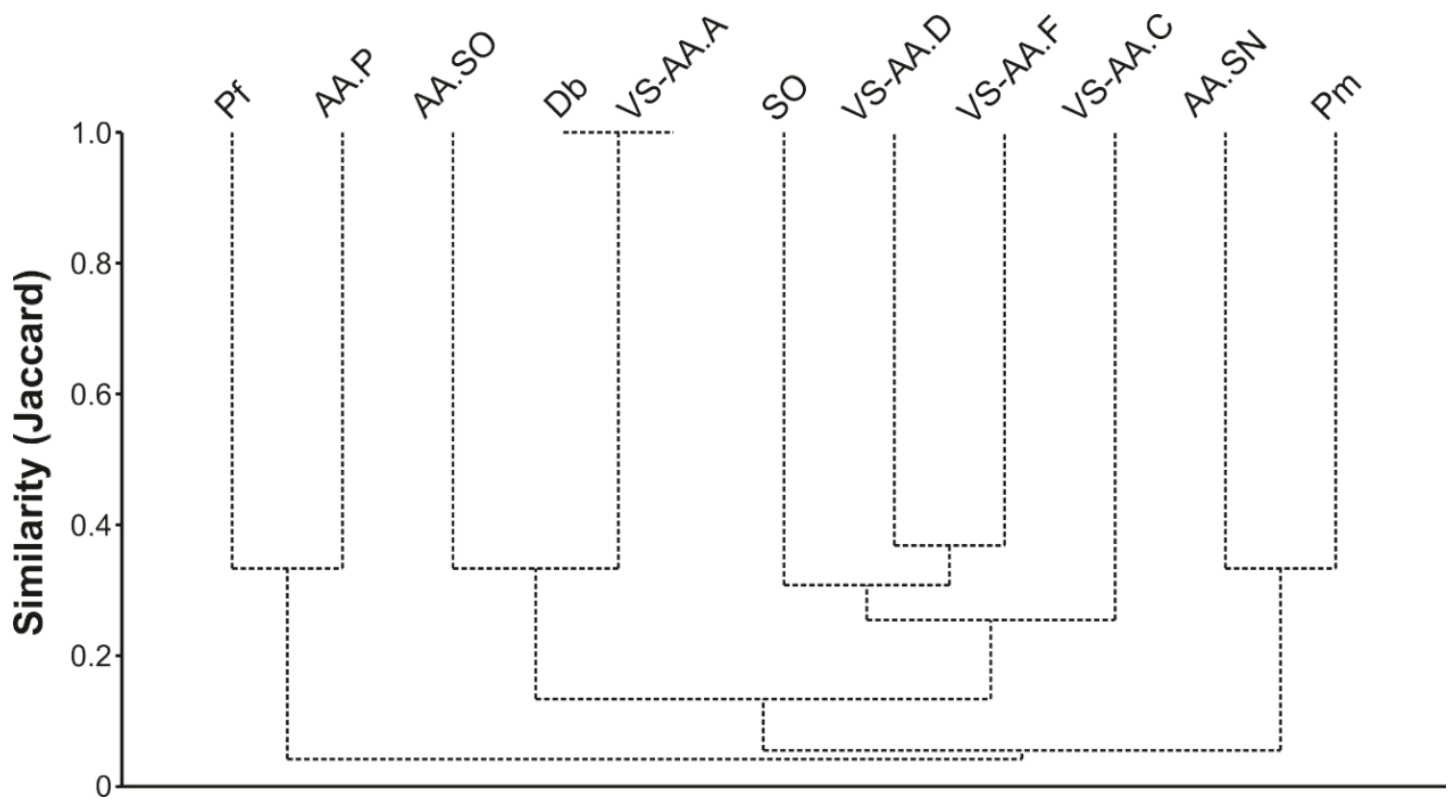

Fig 3. Dendrogram of similarity (Jaccard's distance) comparing the vegetation types of the Atlantic Forest biome, according to the assemblages of species of the genus Neoponera.

obscuricornis (Emery, 1890), an exclusive species of AA.SO (Fig 4). Some species, although found in more than a single type of vegetation, were more frequent with one or two certain types, for example, Neoponera cavinodis Mann, 1916 with $N$. villosa, Neoponera magnifica (Borgmeier, 1929) and
Neoponera bactronica (Fernandes, Oliveira \& Delabie, 2014) with VS-AA.C and AA.SN. In turn, Neoponera verenae Forel, 1922, Neoponera striatinodis (Emery, 1890) and Neoponera crenata (Roger, 1861) group together more with VS-AA.F and AA.P (Fig 4).

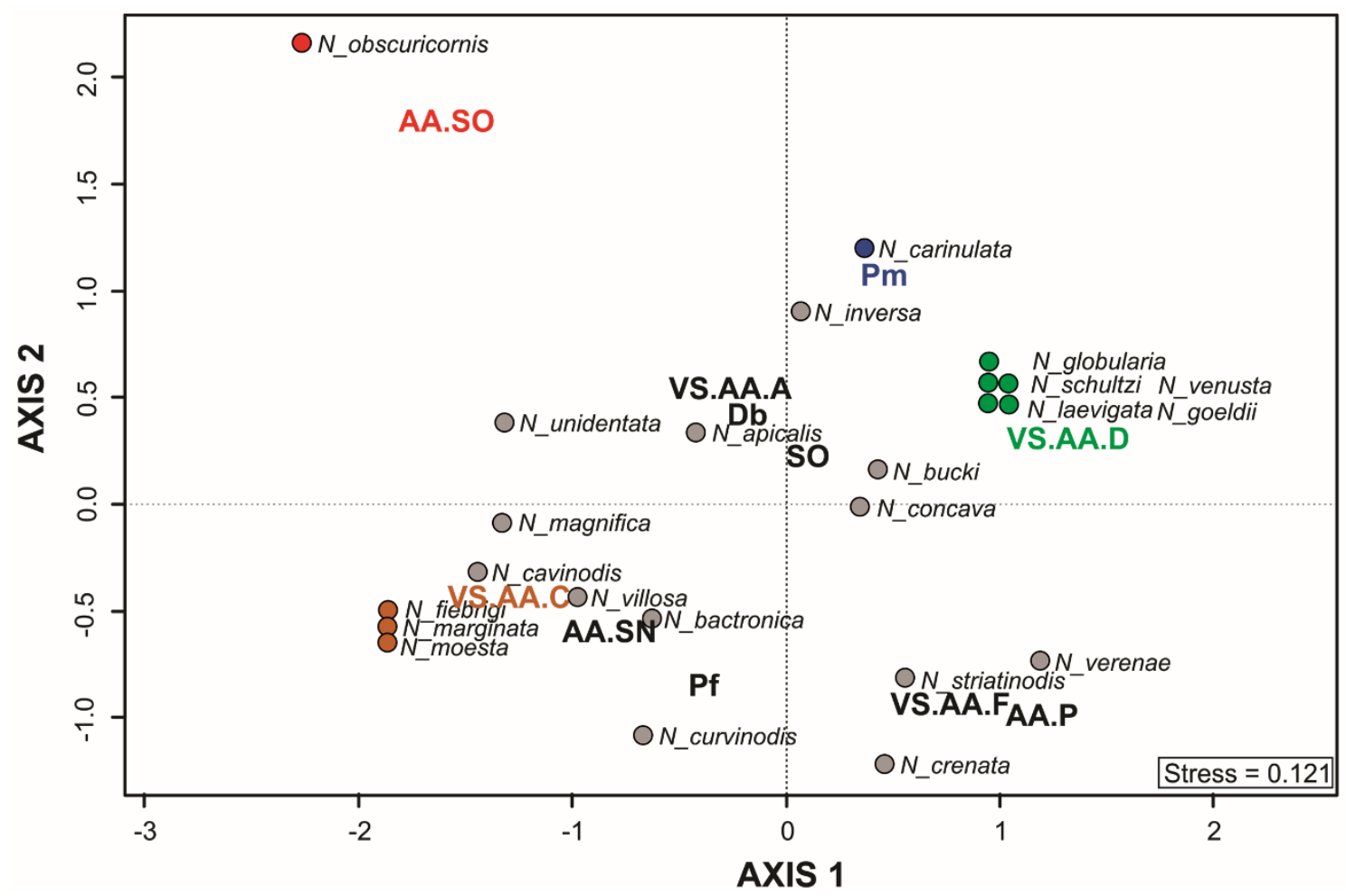

Fig 4. Non-Metric Multidimensional Scaling (NMDS) of vegetation types in the Brazilian Atlantic Forest based on Neoponera frequency of occurrence. Circles filled with the same color = exclusive occurrence in the type of vegetation with equivalent color. 
Table 4. List of Neoponera species reported from the study area. The codes of localities follow Table 3. (*) new record for Brazil, $(* *)$ new record for Atlantic Forest.

\begin{tabular}{|c|c|}
\hline Species & Code \\
\hline Neoponera apicalis & $\begin{array}{l}2,7,10,11,12,14,15,19,24,25, \\
28,29,35,38,39,42,43,46,47 \\
48,57,59,64,66,67,72,73,74, \\
76,77,78,79,82,88\end{array}$ \\
\hline Neoponera bactronica & $5,24,32,41,61,63,92$ \\
\hline Neoponera bucki & $\begin{array}{l}1,3,7,10,22,26,27,28,37,50 \\
55,74,76,80,83\end{array}$ \\
\hline Neoponera carinulata & $10,29,64,78,83$ \\
\hline Neoponera cavinodis & 13,29 \\
\hline Neoponera concava & $\begin{array}{l}1,2,3,9,10,12,13,15,23,25 \\
26,29,33,37,40,46,55,56,66 \\
68,71,75,77,78\end{array}$ \\
\hline Neoponera crenata & $4,31,85$ \\
\hline Neoponera curvinodis & $18,24,29,34,44,49,81,90,91$ \\
\hline Neoponera fiebrigi* & 8,81 \\
\hline Neoponera globularia** & 6,32 \\
\hline Neoponera goeldii & 33 \\
\hline Neoponera inversa & $\begin{array}{l}9,13,21,24,26,29,37,53,55,68, \\
77,78\end{array}$ \\
\hline Neoponera laevigata & 29,78 \\
\hline Neoponera magnifica & $4,17,81$ \\
\hline Neoponera marginata & 62 \\
\hline Neoponera moesta & 4,81 \\
\hline Neoponera obscuricornis & 7 \\
\hline Neoponera schultzi & 43,51 \\
\hline Neoponera striatinodis & 45,86 \\
\hline Neoponera unidentata & $7,20,23,54,65,69,70,77$ \\
\hline Neoponera venusta & $29,77,83$ \\
\hline Neoponera verenae & $16,24,46,52,80,90$ \\
\hline Neoponera villosa & $30,36,46,50,58,83,84,87,89$ \\
\hline
\end{tabular}

\section{Discussion}

So far 35 species were recorded for the Neoponera genus in Brazil (Feitosa, 2015). With this survey and insertion of new records and occurrences, this number can be updated to 36 species, 23 of which are found in the northern part of the Atlantic Forest biome. Thus, N. fiebrigi, previously registered only in Paraguay, Argentina (Mackay \& Mackay 2010) and Panama (Schmidt \& Schattuck, 2014), constitutes a new record for Brazil and the Atlantic Forest.

We observed that the occurrence of many species of the genus Neoponera in the Brazilian Atlantic Forest is related to dense vegetation, such like secondary forests or vegetation at climax. These environments offer a higher number of records and species richness than opened environments. The same was observed by Campiolo et al. (2015) in a study that points out the Ponerinae preferences for forest-type habitats with dense vegetation cover. These characteristics results from the particular habitat requirements of each species of the genus.
For example, N. apicalis, N. villosa, N. carinulata, N. crenata, $N$. curvinodis and $N$. inversa are arboreal (Mackay \& Mackay, 2010). Some species can also nest in undergrowth, trunks and hollow branches fallen on the ground, where moisture and shade conditions are suitable, such as for example, $N$. verenae (Delabie et al., 2008, Araujo et al., 2019).

The species recorded in a higher number of vegetation types, $N$. apicalis, is known to occur in both primary and secondary moist forests (Mackay \& Mackay, 2010). However, Delabie et al. (2008) suggest that the apicalis group of Neoponera (sensu Wild, 2005) is in fact a complex of at least nine cryptic species, including $N$. apicalis, $N$. obscuricornis and $N$. verenae (Ferreira et al., 2010), which could explain the range of habitats chosen by the ants.

The type of vegetation with the higher diversity of Neoponera was the Ombrophilous Dense Forest. This kind of forests presents moist soil covered by a thick layer of leaf-litter (Pereira, 2009). Because it uses to be more heterogeneous in diversified environments, the leaf-litter offers certainly a range of niches and, as a result, a well-diversified community of soil fauna; in addition, we can expect that the greater the amount of leaf-litter, the greater the availability of resources, such as food and nesting sites (Santos et al., 2006; Ferreira et al., 2018). However, the seasonal deciduous and semideciduous forests, which occur in places with 2 to 5 months of dry season (Colombo \& Joly, 2010), also showed a relatively high species richness. Lattke (2003) had already pointed out that some Neoponera species are able to colonize dry forest areas with a marked rainfall regime.

Our observations point out some particularities such as the occurrence of $N$. goeldii in the Atlantic Forest biome, with an extremely reduced population living isolated in the Península de Maraú, Bahia (J.H.C. Delabie, personal communication, December, 2019), while this species is common in Amazon (Mackay \& Mackay, 2010). In fact, there are numerous physiographic, floristic, fauna and climatic similarities between the Atlantic Forest biome, in the coastal strip which runs from the south of the state of Bahia to the north of the state of Espírito Santo ("Central Corridor of the Mata Atlântica"), and the Amazon Forest (Pereira, 2009). According to Joly et al. (1999), the occurrence of species typical of the Amazon region in the Atlantic Forest of southern Bahia confirms that these biomes have undergone expansion and retraction processes during the Pleistocene climatic fluctuations. In other words, at one or several intervals in this period, transition bridges occurred allowing the arrival of typically Amazonian species in the Atlantic Forest biome (Ab'Saber, 2003; Costa, 2003).

The ant species Neoponera globularia, $N$. goeldii, $N$. laevigata, $N$. schultzi and $N$. venusta follow the same patterns of geographical distribution in the Atlantic Forest, occupying exclusively areas of Ombrophilous Dense Forest. The same occurs with $N$ fiebrigi, $N$. marginata and $N$. moesta, in the Seasonal Deciduous Forest. Neoponera schultzi and N. venusta, 
Table 3. Information from the sampled sites. The abbreviations vegetation type follows those reported in Table 1.

\begin{tabular}{|c|c|c|c|c|}
\hline State & County & Coordinate & Vegetation type & Code \\
\hline \multirow[t]{2}{*}{ Alagoas } & Quebrângulo & $9.3167 \mathrm{~S}, 36.4667 \mathrm{~W}$ & VS-AA.F & 1 \\
\hline & & $9.322 \mathrm{~S}, 36.476 \mathrm{~W}$ & VS-AA.F & \\
\hline \multirow[t]{51}{*}{ Bahia } & Arataca & $15.2195 \mathrm{~S}, 39.4243 \mathrm{~W}$ & VS-AA.D & 2 \\
\hline & & $15.2803 \mathrm{~S}, 39.3919 \mathrm{~W}$ & VS-AA.D & \\
\hline & Aurelino Leal & $14.3311 \mathrm{~S}, 39.3589 \mathrm{~W}$ & VS-AA.D & 3 \\
\hline & & 14.3679S, 39.4657W & VS-AA.D & \\
\hline & & $14.3828 \mathrm{~S}, 39.4156 \mathrm{~W}$ & VS-AA.D & \\
\hline & Barra do Choça & $14.8081 \mathrm{~S}, 40.5897 \mathrm{~W}$ & VS-AA.D & 4 \\
\hline & & $14.8333 \mathrm{~S}, 40.5536 \mathrm{~W}$ & VS-AA.D & \\
\hline & & $14.8659 \mathrm{~S}, 40.5779 \mathrm{~W}$ & VS-AA.D & \\
\hline & Barra do Rocha & $14.2068 \mathrm{~S}, 39.6031 \mathrm{~W}$ & VS-AA.C & 5 \\
\hline & Barro Preto & $14.8097 \mathrm{~S}, 39.4233 \mathrm{~W}$ & VS-AA.D & 6 \\
\hline & Belmonte & $16.0951 \mathrm{~S}, 39.2745 \mathrm{~W}$ & VS-AA.D & 7 \\
\hline & & $16.1333 \mathrm{~S}, 39.25 \mathrm{~W}$ & AA.SO & \\
\hline & & $16.1 \mathrm{~S}, 39.2833 \mathrm{~W}$ & AA.SO & \\
\hline & Boa Nova & $14.3656 \mathrm{~S}, 40.2075 \mathrm{~W}$ & AA.SO & 8 \\
\hline & Buerarema & $14.6333 \mathrm{~S}, 39.8833 \mathrm{~W}$ & VS-AA.D & 9 \\
\hline & & $14.7583 \mathrm{~S}, 39.2411 \mathrm{~W}$ & VS-AA.C & \\
\hline & & $15.0144 \mathrm{~S}, 39.2999 \mathrm{~W}$ & VS-AA.F & \\
\hline & Camacan & $15.3833 \mathrm{~S}, 39.55 \mathrm{~W}$ & VS-AA.D & 10 \\
\hline & & $15.4011 \mathrm{~S}, 39.5664 \mathrm{~W}$ & VS-AA.D & \\
\hline & & $15.4167 \mathrm{~S}, 39.4833 \mathrm{~W}$ & VS-AA.D & \\
\hline & & $15.4201 \mathrm{~S}, 39.4964 \mathrm{~W}$ & VS-AA.D & \\
\hline & & $15.4573 \mathrm{~S}, 39.4516 \mathrm{~W}$ & VS-AA.D & \\
\hline & & $15.5006 \mathrm{~S}, 39.2206 \mathrm{~W}$ & VS-AA.D & \\
\hline & & $15.5036 \mathrm{~S}, 39.5156 \mathrm{~W}$ & VS-AA.D & \\
\hline & & $15.6011 \mathrm{~S}, 39.5211 \mathrm{~W}$ & VS-AA.D & \\
\hline & Camaçari & $12.6972 \mathrm{~S}, 38.3332 \mathrm{~W}$ & VS-AA.D & 11 \\
\hline & Camamu & $13.9443 \mathrm{~S}, 39.1046 \mathrm{~W}$ & VS-AA.D & 12 \\
\hline & & $14.0142 \mathrm{~S}, 39.1667 \mathrm{~W}$ & VS-AA.D & \\
\hline & & $14.1369 \mathrm{~S}, 39.2775 \mathrm{~W}$ & VS-AA.D & \\
\hline & Canavieiras & $14.4094 \mathrm{~S}, 39.0337 \mathrm{~W}$ & VS-AA.C & 13 \\
\hline & & $15.6752 \mathrm{~S}, 38.9969 \mathrm{~W}$ & VS-AA.D & \\
\hline & & $15.6775 \mathrm{~S}, 39.9783 \mathrm{~W}$ & VS-AA.D & \\
\hline & Caravelas & $17.6794 \mathrm{~S}, 39.6105 \mathrm{~W}$ & $\mathrm{Pm}$ & 14 \\
\hline & Cruz das Almas & $12.6736 \mathrm{~S}, 39.1017 \mathrm{~W}$ & VS-AA.F & 15 \\
\hline & & $12.6799 \mathrm{~S}, 39.0891 \mathrm{~W}$ & VS-AA.D & \\
\hline & Ecoporanga & $18.3709 \mathrm{~S}, 40.8329 \mathrm{~W}$ & VS-AA.F & 16 \\
\hline & Esplanada & $12.1144 \mathrm{~S}, 37.6969 \mathrm{~W}$ & VS-AA.D & 17 \\
\hline & Estância & $11.2687 \mathrm{~S}, 37.4385 \mathrm{~W}$ & $\mathrm{SO}$ & 18 \\
\hline & Eunápolis & $16.372 \mathrm{~S}, 39.5825 \mathrm{~W}$ & VS-AA.F & 19 \\
\hline & Firmino Alves & $14.9247 \mathrm{~S}, 39.9196 \mathrm{~W}$ & VS-AA.D & 20 \\
\hline & Floresta Azul & $14.8761 \mathrm{~S}, 39.6931 \mathrm{~W}$ & VS-AA.C & 21 \\
\hline & Gongogi & 14.2742S, 39.4842W & VS-AA.D & 22 \\
\hline & & $15.2742 \mathrm{~S}, 39.4842 \mathrm{~W}$ & VS-AA.D & \\
\hline & Governador Lomanto Junior & $14.8158 \mathrm{~S}, 39.4839 \mathrm{~W}$ & VS-AA.D & 23 \\
\hline & Guaratinga & $16.5625 \mathrm{~S}, 39.899 \mathrm{~W}$ & VS-AA.D & 24 \\
\hline & & $16.5867 \mathrm{~S}, 39.7753 \mathrm{~W}$ & VS-AA.D & \\
\hline & & $16.5867 \mathrm{~S}, 39.7808 \mathrm{~W}$ & VS-AA.D & \\
\hline & & $16.6286 \mathrm{~S}, 39.7983 \mathrm{~W}$ & VS-AA.D & \\
\hline & Ibicaraí & $14.8583 \mathrm{~S}, 39.5918 \mathrm{~W}$ & VS-AA.D & 25 \\
\hline & & $14.9042 \mathrm{~S}, 39.4836 \mathrm{~W}$ & VS-AA.F & \\
\hline & Ibirapitanga & $14.0709 \mathrm{~S}, 39.4243 \mathrm{~W}$ & VS-AA.D & 26 \\
\hline
\end{tabular}


Table 3. Information from the sampled sites. The abbreviations vegetation type follows those reported in Table 1. (Continuation)

\begin{tabular}{|c|c|c|c|c|}
\hline State & County & Coordinate & Vegetation type & Code \\
\hline & & $14.1942 \mathrm{~S}, 39.4231 \mathrm{~W}$ & VS-AA.F & \\
\hline & Igrapiúna & $13.8448 \mathrm{~S}, 39.1127 \mathrm{~W}$ & VS-AA.D & 27 \\
\hline & Iguaí & $14.6416 \mathrm{~S}, 39.198 \mathrm{~W}$ & VS-AA.D & 28 \\
\hline & & $14.6439 \mathrm{~S}, 40.1533 \mathrm{~W}$ & VS-AA.D & \\
\hline & Ilhéus & $14.255 \mathrm{~S}, 39.2314 \mathrm{~W}$ & VS-AA.D & 29 \\
\hline & & $14.4274 \mathrm{~S}, 39.5705 \mathrm{~W}$ & VS-AA.D & \\
\hline & & $14.5006 \mathrm{~S}, 39.0676 \mathrm{~W}$ & VS-AA.D & \\
\hline & & $14.5294 \mathrm{~S}, 39.0661 \mathrm{~W}$ & VS-AA.D & \\
\hline & & $14.5533 \mathrm{~S}, 39.4275 \mathrm{~W}$ & VS-AA.D & \\
\hline & & $14.6207 \mathrm{~S}, 39.1397 \mathrm{~W}$ & VS-AA.D & \\
\hline & & $14.6808 \mathrm{~S}, 39.2567 \mathrm{~W}$ & VS-AA.D & \\
\hline & & $14.6935 \mathrm{~S}, 39.0966 \mathrm{~W}$ & VS-AA.D & \\
\hline & & $14.7422 \mathrm{~S}, 39.1056 \mathrm{~W}$ & VS-AA.D & \\
\hline & & $14.755 \mathrm{~S}, 39.2314 \mathrm{~W}$ & VS-AA.D & \\
\hline & & $14.7561 \mathrm{~S}, 39.2314 \mathrm{~W}$ & VS-AA.D & \\
\hline & & $14.7813 \mathrm{~S}, 39.0795 \mathrm{~W}$ & VS-AA.D & \\
\hline & & $14.7935 \mathrm{~S}, 39.0774 \mathrm{~W}$ & VS-AA.D & \\
\hline & & $14.7961 \mathrm{~S}, 39.211 \mathrm{~W}$ & VS-AA.D & \\
\hline & & $14.7972 \mathrm{~S}, 39.0798 \mathrm{~W}$ & VS-AA.D & \\
\hline & & 14.798S, 39.1722W & VS-AA.D & \\
\hline & & $14.8239 \mathrm{~S}, 39.1 \mathrm{~W}$ & VS-AA.D & \\
\hline & & $14.9197 \mathrm{~S}, 39.1997 \mathrm{~W}$ & VS-AA.D & \\
\hline & & $14.9504 \mathrm{~S}, 39.0631 \mathrm{~W}$ & VS-AA.F & \\
\hline & & $14.9903 \mathrm{~S}, 39.0583 \mathrm{~W}$ & VS-AA.F & \\
\hline & Ipiaú & $14.1349 \mathrm{~S}, 39.7386 \mathrm{~W}$ & VS-AA.D & 30 \\
\hline & Itabira & $19.7501 \mathrm{~S}, 43.2323 \mathrm{~W}$ & VS-AA.D & 31 \\
\hline & Itabuna & $14.7772 \mathrm{~S}, 39.3674 \mathrm{~W}$ & VS-AA.D & 32 \\
\hline & & $14.78 \mathrm{~S}, 39.2784 \mathrm{~W}$ & VS-AA.D & \\
\hline & Itacaré & $14.2794 \mathrm{~S}, 39.4852 \mathrm{~W}$ & VS-AA.F & 33 \\
\hline & & $14.3092 \mathrm{~S}, 39.0194 \mathrm{~W}$ & VS-AA.D & \\
\hline & & $14.3568 \mathrm{~S}, 39.1752 \mathrm{~W}$ & VS-AA.F & \\
\hline & Itagi & $14.2329 \mathrm{~S}, 39.8579 \mathrm{~W}$ & VS-AA.C & 34 \\
\hline & Itagibá & $14.233 \mathrm{~S}, 39.8579 \mathrm{~W}$ & VS-AA.D & 35 \\
\hline & Itaju do Colônia & $15.1652 \mathrm{~S}, 39.7756 \mathrm{~W}$ & VS-AA.D & 36 \\
\hline & Itajuípe & $14.6757 \mathrm{~S}, 39.3725 \mathrm{~W}$ & VS-AA.D & 37 \\
\hline & & $14.7033 \mathrm{~S}, 39.4981 \mathrm{~W}$ & VS-AA.D & \\
\hline & Itamaraju & $16.8675 \mathrm{~S}, 39.9175 \mathrm{~W}$ & VS-AA.D & 38 \\
\hline & & $16.9167 \mathrm{~S}, 39.2667 \mathrm{~W}$ & VS-AA.D & \\
\hline & & $16.9917 \mathrm{~S}, 39.4553 \mathrm{~W}$ & VS-AA.D & \\
\hline & & $17.0382 \mathrm{~S}, 39.5389 \mathrm{~W}$ & VS-AA.D & \\
\hline & Itamari & $13.7273 \mathrm{~S}, 39.6312 \mathrm{~W}$ & VS-AA.D & 39 \\
\hline & Itambé & $14.6519 \mathrm{~S}, 40.3397 \mathrm{~W}$ & VS-AA.F & 40 \\
\hline & Itapebi & $15.9693 \mathrm{~S}, 39.5321 \mathrm{~W}$ & VS-AA.D & 41 \\
\hline & Itapetinga & $15.2461 \mathrm{~S}, 39.9403 \mathrm{~W}$ & VS-AA.D & 42 \\
\hline & Itapitanga & $14.4228 \mathrm{~S}, 39.565 \mathrm{~W}$ & VS-AA.D & 43 \\
\hline & & $14.4319 \mathrm{~S}, 39.565 \mathrm{~W}$ & VS-AA.F & \\
\hline & & $14.5108 \mathrm{~S}, 39.6105 \mathrm{~W}$ & VS-AA.D & \\
\hline & Itaquara & $13.4537 \mathrm{~S}, 39.8785 \mathrm{~W}$ & VS-AA.D & 44 \\
\hline & Itati & $13.9572 \mathrm{~S}, 40.0308 \mathrm{~W}$ & VS-AA.C & 45 \\
\hline & Itororó & $14.9586 \mathrm{~S}, 39.0643 \mathrm{~W}$ & VS-AA.C & 46 \\
\hline & & $14.9586 \mathrm{~S}, 40.0425 \mathrm{~W}$ & VS-AA.F & \\
\hline & & $14.9614 \mathrm{~S}, 40.0425 \mathrm{~W}$ & VS-AA.D & \\
\hline & & $14.9778 \mathrm{~S}, 40.0364 \mathrm{~W}$ & VS-AA.D & \\
\hline
\end{tabular}


Table 3. Information from the sampled sites. The abbreviations vegetation type follows those reported in Table 1. (Continuation)

\begin{tabular}{|c|c|c|c|c|}
\hline State & County & Coordinate & Vegetation type & Code \\
\hline & & $15.1185 \mathrm{~S}, 40.0661 \mathrm{~W}$ & VS-AA.D & \\
\hline & & $15.4744 \mathrm{~S}, 40.0503 \mathrm{~W}$ & VS-AA.D & \\
\hline & Ituberá & $13.736 \mathrm{~S}, 39.1466 \mathrm{~W}$ & VS-AA.C & 47 \\
\hline & Jaguaripe & $13.1956 \mathrm{~S}, 39.0239 \mathrm{~W}$ & VS-AA.D & 48 \\
\hline & Jequié & $13.8591 \mathrm{~S}, 40.0838 \mathrm{~W}$ & AA.SN & 49 \\
\hline & Jiquiriçá & $13.3193 \mathrm{~S}, 39.5899 \mathrm{~W}$ & VS-AA.D & 50 \\
\hline & Jussari & $15.1406 \mathrm{~S}, 39.5247 \mathrm{~W}$ & VS-AA.D & 51 \\
\hline & & $15.1535 \mathrm{~S}, 39.5167 \mathrm{~W}$ & AA.P & \\
\hline & Laje & $13.1761 \mathrm{~S}, 39.3414 \mathrm{~W}$ & $\mathrm{Pm}$ & 52 \\
\hline & Lauro de Freitas & $12.8642 \mathrm{~S}, 38.2697 \mathrm{~W}$ & VS-AA.D & 53 \\
\hline & Macarani & $15.5303 \mathrm{~S}, 40.3905 \mathrm{~W}$ & VS-AA.D & 54 \\
\hline & Maraú & $14.1503 \mathrm{~S}, 39.1127 \mathrm{~W}$ & SO & 55 \\
\hline & Mascote & $13.7189 \mathrm{~S}, 39.41 \mathrm{~W}$ & VS-AA.D & 56 \\
\hline & & $15.5636 \mathrm{~S}, 39.3094 \mathrm{~W}$ & VS-AA.D & \\
\hline & & $15.5772 \mathrm{~S}, 39.41 \mathrm{~W}$ & SO & \\
\hline & & $15.6969 \mathrm{~S}, 39.445 \mathrm{~W}$ & VS-AA.D & \\
\hline & & $15.7344 \mathrm{~S}, 39.3844 \mathrm{~W}$ & VS-AA.D & \\
\hline & Mucuri & $18.0825 \mathrm{~S}, 39.8909 \mathrm{~W}$ & VS-AA.D & 57 \\
\hline & Mutuípe & $13.2288 \mathrm{~S}, 39.5047 \mathrm{~W}$ & VS-AA.D & 58 \\
\hline & Nazaré & $13.0399 \mathrm{~S}, 39.0034 \mathrm{~W}$ & VS-AA.D & 59 \\
\hline & Nilo Peçanha & $13.6494 \mathrm{~S}, 39.2103 \mathrm{~W}$ & VS-AA.D & 60 \\
\hline & Pau Brasil & $15.4897 \mathrm{~S}, 39.6931 \mathrm{~W}$ & VS-AA.D & 61 \\
\hline & Planalto & $14.6991 \mathrm{~S}, 40.4772 \mathrm{~W}$ & VS-AA.C & 62 \\
\hline & Poções & $14.6147 \mathrm{~S}, 40.3411 \mathrm{~W}$ & VS-AA.C & 63 \\
\hline & Porto Seguro & $15.6694 \mathrm{~S}, 38.9942 \mathrm{~W}$ & $\mathrm{Pm}$ & 64 \\
\hline & & $16.3883 \mathrm{~S}, 39.1814 \mathrm{~W}$ & $\mathrm{Db}$ & \\
\hline & & $16.4444 \mathrm{~S}, 39.0984 \mathrm{~W}$ & VS-AA.D & \\
\hline & Pratas & $15.1956 \mathrm{~S}, 39.4453 \mathrm{~W}$ & VS-AA.D & 65 \\
\hline & Presidente Tancredo Neves & $13.3911 \mathrm{~S}, 39.3183 \mathrm{~W}$ & VS-AA.D & 66 \\
\hline & Salvador & $12.9292 \mathrm{~S}, 38.5014 \mathrm{~W}$ & VS-AA.D & 67 \\
\hline & & $12.9722 \mathrm{~S}, 38.5014 \mathrm{~W}$ & VS-AA.D & \\
\hline & Santa Luzia & $15.3897 \mathrm{~S}, 39.305 \mathrm{~W}$ & VS-AA.D & 68 \\
\hline & & $15.4233 \mathrm{~S}, 39.2791 \mathrm{~W}$ & VS-AA.D & \\
\hline & Santo Amaro & $12.5465 \mathrm{~S}, 38.7111 \mathrm{~W}$ & VS-AA.D & 69 \\
\hline & São Francisco do Conde & $12.6655 \mathrm{~S}, 38.59 \mathrm{~W}$ & VS-AA.D & 70 \\
\hline & São José da Vitória & $15.0517 \mathrm{~S}, 39.3133 \mathrm{~W}$ & VS-AA.D & 71 \\
\hline & & $15.0617 \mathrm{~S}, 39.3442 \mathrm{~W}$ & VS-AA.D & \\
\hline & Simões Filho & $12.7701 \mathrm{~S}, 38.4219 \mathrm{~W}$ & VS-AA.D & 72 \\
\hline & & $12.7717 \mathrm{~S}, 39.5219 \mathrm{~W}$ & VS-AA.C & \\
\hline & Teixeira de Freitas & $17.54 \mathrm{~S}, 39.7422 \mathrm{~W}$ & VS-AA.D & 73 \\
\hline & Ubaíra & $13.1192 \mathrm{~S}, 39.6594 \mathrm{~W}$ & VS-AA.D & 74 \\
\hline & Ubaitaba & $14.2503 \mathrm{~S}, 39.3214 \mathrm{~W}$ & VS-AA.D & 75 \\
\hline & & $14.2503 \mathrm{~S}, 39.3242 \mathrm{~W}$ & VS-AA.D & \\
\hline & & 14.3089S, 39.3226W & VS-AA.D & \\
\hline & & $14.4247 \mathrm{~S}, 39.3233 \mathrm{~W}$ & VS-AA.D & \\
\hline & Ubatã & $14.0699 \mathrm{~S}, 39.5278 \mathrm{~W}$ & VS-AA.D & 76 \\
\hline & & $14.2256 \mathrm{~S}, 39.4656 \mathrm{~W}$ & VS-AA.D & \\
\hline & Una & $15.0892 \mathrm{~S}, 39.295 \mathrm{~W}$ & VS-AA.D & 77 \\
\hline & & $15.177 \mathrm{~S}, 39.1055 \mathrm{~W}$ & VS-AA.D & \\
\hline & & $15.1844 \mathrm{~S}, 39.0546 \mathrm{~W}$ & $\mathrm{SO}$ & \\
\hline & & 15.2028S, 39.0531W & $\mathrm{SO}$ & \\
\hline & & 15.2091S, 39.196W & VS-AA.D & \\
\hline & & $15.2336 \mathrm{~S}, 39.1844 \mathrm{~W}$ & VS-AA.D & \\
\hline
\end{tabular}


Table 3. Information from the sampled sites. The abbreviations vegetation type follows those reported in Table 1. (Continuation)

\begin{tabular}{|c|c|c|c|c|}
\hline State & County & Coordinate & Vegetation type & Code \\
\hline & & $15.2617 \mathrm{~S}, 39.1533 \mathrm{~W}$ & $\mathrm{SO}$ & \\
\hline & & $15.2792 \mathrm{~S}, 39.0414 \mathrm{~W}$ & $\mathrm{SO}$ & \\
\hline & & $15.2792 \mathrm{~S}, 39.0914 \mathrm{~W}$ & $\mathrm{SO}$ & \\
\hline & & $15.2795 \mathrm{~S}, 39.0769 \mathrm{~W}$ & SO & \\
\hline & & $15.2808 \mathrm{~S}, 39.089 \mathrm{~W}$ & SO & \\
\hline & & $15.2858 \mathrm{~S}, 39.1175 \mathrm{~W}$ & $\mathrm{SO}$ & \\
\hline & & $15.3897 \mathrm{~S}, 39.1975 \mathrm{~W}$ & SO & \\
\hline & Uruçuca & $14.4514 \mathrm{~S}, 39.0478 \mathrm{~W}$ & VS-AA.D & 78 \\
\hline & & $14.4649 \mathrm{~S}, 39.0532 \mathrm{~W}$ & VS-AA.D & \\
\hline & & $14.465 \mathrm{~S}, 39.0567 \mathrm{~W}$ & VS-AA.D & \\
\hline & & $14.5125 \mathrm{~S}, 39.2003 \mathrm{~W}$ & VS-AA.D & \\
\hline & & $14.5155 \mathrm{~S}, 39.2999 \mathrm{~W}$ & VS-AA.D & \\
\hline & & $14.5653 \mathrm{~S}, 39.2739 \mathrm{~W}$ & VS-AA.D & \\
\hline & & $14.6 \mathrm{~S}, 39.2667 \mathrm{~W}$ & VS-AA.D & \\
\hline & Valença & $13.3422 \mathrm{~S}, 39.1953 \mathrm{~W}$ & VS-AA.D & 79 \\
\hline & & $13.3709 \mathrm{~S}, 39.0759 \mathrm{~W}$ & VS-AA.D & \\
\hline & Vera Cruz & $13.0229 \mathrm{~S}, 38.7159 \mathrm{~W}$ & VS-AA.D & 80 \\
\hline & Vitória da Conquista & $14.7936 \mathrm{~S}, 40.7231 \mathrm{~W}$ & VS-AA.C & 81 \\
\hline & & $14.8411 \mathrm{~S}, 40.8389 \mathrm{~W}$ & VS-AA.C & \\
\hline & & $14.8619 \mathrm{~S}, 40.8445 \mathrm{~W}$ & VS-AA.C & \\
\hline & & $14.8892 \mathrm{~S}, 40.8034 \mathrm{~W}$ & VS-AA.D & \\
\hline & & $15.0392 \mathrm{~S}, 40.9097 \mathrm{~W}$ & VS-AA.C & \\
\hline & Wenceslau Guimarães & $13.5539 \mathrm{~S}, 39.7019 \mathrm{~W}$ & VS-AA.D & 82 \\
\hline & & $13.5832 \mathrm{~S}, 39.6931 \mathrm{~W}$ & VS-AA.D & \\
\hline \multirow[t]{5}{*}{ Espírito Santo } & Linhares & $19.1514 \mathrm{~S}, 40.0708 \mathrm{~W}$ & VS-AA.C & 83 \\
\hline & & $19.15 \mathrm{~S}, 40.05 \mathrm{~W}$ & VS-AA.D & \\
\hline & & $19.3947 \mathrm{~S}, 40.0653 \mathrm{~W}$ & VS-AA.D & \\
\hline & & $19.6455 \mathrm{~S}, 39.855 \mathrm{~W}$ & VS-AA.D & \\
\hline & São Mateus & $18.7002 \mathrm{~S}, 40.0633 \mathrm{~W}$ & VS-AA.D & 84 \\
\hline \multirow[t]{2}{*}{ Minas Gerais } & Guanhães & $18.7667 \mathrm{~S}, 42.9167 \mathrm{~W}$ & VS-AA.D & 85 \\
\hline & Timóteo & $19.5816 \mathrm{~S}, 42.6475 \mathrm{~W}$ & VS-AA.F & 86 \\
\hline Paraíba & João Pessoa & $7.1195 \mathrm{~S}, 34.855 \mathrm{~W}$ & VS-AA.D & 87 \\
\hline Pernambuco & São Lourenço da Mata & $7.9 \mathrm{~S}, 35.0833 \mathrm{~W}$ & VS-AA.A & 88 \\
\hline Rio Grande do Norte & Parnamirim & $5.9072 \mathrm{~S}, 35.1984 \mathrm{~W}$ & $\mathrm{Pm}$ & 89 \\
\hline \multirow[t]{3}{*}{ Sergipe } & Laranjeiras & $10.8122 \mathrm{~S}, 37.1711 \mathrm{~W}$ & VS-AA.D & 90 \\
\hline & Santa Luzia do Itanhy & $11.419 \mathrm{~S}, 37.4284 \mathrm{~W}$ & AA.P & 91 \\
\hline & São Cristóvão & $10.9238 \mathrm{~S}, 37.1019 \mathrm{~W}$ & Pf & 92 \\
\hline
\end{tabular}

together with $N$. concava, which likewise predominates in dense forest, are endemic from Brazil (Mackay \& Mackay, 2010). In the Atlantic Forest, four areas of endemism are reported (Silva et al., 2004; Sigrist \& Carvalho, 2008; Peres et al., 2020), and three of which are considered in our area of study: i) Central Bahia, ii) Central Corridor of the Atlantic Forest, and iii) Pernambuco. These are biogeographic regions supported by several taxonomic groups, being a valid representation of regionalization for studies and conservation of biodiversity (Peres et al., 2020). The Neoponera data obtained in our study basically comprise records for the Central Corridor of the Atlantic Forest, an area of endemism that extends from the south of the state of Bahia to the north of Espírito Santo, with N. schultzi being an endemic species of that region. Thus, we understand that the occurrences of ants reinforce the importance of the conservation of these ants in the Central Corridor of the Atlantic Forest.

Some studies carried out in the Atlantic Forest (Santos et al., 2006; Silva et al., 2007) have shown that ant communities use to be affected by anthropogenic disturbances. It is expected that in areas where landscape fragmentation is dominant and land use is excessive and disordered, many species will not be able to face climatic changes and migrate at a sufficient rate to maintain their population (Pearson \& Dawson, 2003). 
Table 5. References of the data sources used in the study.

\begin{tabular}{|c|c|c|}
\hline Species & State & References \\
\hline \multirow[t]{2}{*}{ Neoponera apicalis } & Bahia & $1,3,9,11,14,19,22,23,25,26,31,34$ \\
\hline & Pernambuco & 33 \\
\hline \multirow[t]{2}{*}{ Neoponera bactronica } & Bahia & $1,5,12,13,15,35$ \\
\hline & Sergipe & 1,13 \\
\hline \multirow[t]{3}{*}{ Neoponera bucki } & Alagoas & 10,36 \\
\hline & Bahia & 1,34 \\
\hline & Espírito Santo & 2,36 \\
\hline \multirow[t]{2}{*}{ Neoponera carinulata } & Bahia & $1,23,25,34$ \\
\hline & Espírito Santo & 1 \\
\hline Neoponera cavinodis & Bahia & $1,6,34$ \\
\hline \multirow[t]{4}{*}{ Neoponera concava } & Alagoas & 1 \\
\hline & Bahia & $1,6,26,28,32,34$ \\
\hline & Espírito Santo & 2 \\
\hline & Sergipe & 1 \\
\hline \multirow[t]{3}{*}{ Neoponera crenata } & Alagoas & 10 \\
\hline & Bahia & $1,2,5,7,15,23,24,25,27,34$ \\
\hline & Minas Gerais & 1 \\
\hline \multirow[t]{2}{*}{ Neoponera curvinodis } & Bahia & $1,3,7,13,25,27,34,35$ \\
\hline & Sergipe & 1,13 \\
\hline Neoponera fiebrigi & Bahia & 1 \\
\hline Neoponera globularia & Bahia & 1 \\
\hline Neoponera goeldii & Bahia & $1,18,21$ \\
\hline \multirow[t]{3}{*}{ Neoponera inversa } & Alagoas & 10 \\
\hline & Bahia & $1,3,5,7,8,10,13,15,17,20,25,35,37$ \\
\hline & Espírito Santo & 13 \\
\hline Neoponera laevigata & Bahia & 1,28 \\
\hline Neoponera magnifica & Bahia & $1,15,26$ \\
\hline Neoponera marginata & Bahia & 1,34 \\
\hline Neoponera moesta & Bahia & $1,7,8,15,24,25,34$ \\
\hline Neoponera obscuricornis & Bahia & 1,31 \\
\hline Neoponera schultzi & Bahia & 1,34 \\
\hline \multirow[t]{2}{*}{ Neoponera striatinodis } & Bahia & $1,19,34$ \\
\hline & Minas Gerais & 1 \\
\hline Neoponera unidentata & Bahia & $1,5,7,11,14,15,21,22,23,25$ \\
\hline \multirow[t]{3}{*}{ Neoponera venusta } & Alagoas & 30 \\
\hline & Bahia & $1,4,9,11,14,21,25,28,30,31$ \\
\hline & Espírito Santo & $1,2,11,36$ \\
\hline \multirow[t]{3}{*}{ Neoponera verenae } & Bahia & $1,3,11,19,25,26,30,34$ \\
\hline & Espírito Santo & 1,2 \\
\hline & Sergipe & 1,16 \\
\hline \multirow[t]{4}{*}{ Neoponera villosa } & Bahia & $1,5,7,8,9,12,13,14,20,23,25,29,31,34,35$ \\
\hline & Espírito Santo & $1,13,35$ \\
\hline & Paraíba & 1,13 \\
\hline & Rio Grande do Norte & 1 \\
\hline
\end{tabular}

References corresponding to the codes are available in the annex.

Nevertheless, we observed here that the vegetation types with the higher diversity of Neoponera correspond to landscapes with secondary forests in association with agriculture. This has important implications for the future of the biome conservation, since it suggests that secondary forests conserve an important pool of species that, face to the climatic changes, will contribute to the genus resilience in the region.
Since ants are organisms faithful for a specific type of habitat, and may allow inferences about the rehabilitation of an area (Schmidt et al., 2013), the occurrence of some Neoponera in more than a single type of vegetation, like $N$. apicalis, $N$. villosa, N. bucki, N. curvinodis, Neoponera unidentata (Mayr, 1862) and N. inversa (Fig 4), strongly suggest the connectivity between vegetation types. Thus, the conservation of forest 
remnants and even some kinds of agriculture which maintains a forest structure (cocoa agroforestry, for example) can be decisive for the conservation of this group of ants (Delabie et al., 2007; Campiolo et al., 2015). Further studies should evaluate the relationships between the occurrence and distribution of the species of Neoponera and the habitat conservation including also the other areas covered by the biome.

\section{Acknowledgments}

This study is part of the requirements for the obtention of the first author's Master Degree. Thanks are due to the Programa de Pós-Graduação em Zoologia of State University of Santa Cruz (UESC). This study was financed in part by the Coordenação de Aperfeiçoamento de Pessoal de Nível Superior - Brasil (CAPES) - Finance Code 001. PSS acknowledges her study grant from CAPES; JHCD and CSFM thank CNPq (Conselho Nacional de Desenvolvimento Científico e Tecnológico) for their research grants.

\section{Author Contributions}

All authors conceived this study, PSS and EA conducted performed research/acquisition of data. E.B.A.K performed the data analyses. All authors contributed to the writing, discussed the results and commented on the manuscript.

\section{References}

Ab'Sáber, A. N. (2003). Os domínios de natureza no Brasil: potencialidades paisagísticas. 3. ed. São Paulo: Ateliê Editorial.

Antmaps.org. (2018). Available from https://antmaps.org (accessed date: July-September 2018).

AntWeb.org. 2018. Available from https://www.antweb.org (accessed date: July-September 2018).

Araujo, E.S., Koch, E.B.A., Delabie, J.H.C., Zeppelini, D., DaRocha, W.D., Castaño-Meneses, G. \& Mariano, C.S.F. (2019): Diversity of commensals within nests of ants of the genus Neoponera (Hymenoptera: Formicidae: Ponerinae) in Bahia, Brazil. Annales de la Société entomologique de France (N.S.), 55: 291-299. doi: 10.1080/00379271.2019.1629837

Azevedo-Santos, V.M., Castilho, M.C.A., Pelicice, F.M., Vitule, J.R.S., Garcia, D.A.Z. \& Esteves, F.A. (2016). A dura lição com a tragédia do rio Doce. Boletim AB Limno, 42: 0913. doi: 10.13140/RG.2.1.1270.5688

Campiolo, S., Rosario, N. A., Strenzel, G.M.R., Feitosa, R. \& Delabie, J.H.C. (2015). Conservação de Poneromorfas no Brasil. In: Delabie, J.H.C., Feitosa, R., Serrão, J. E., Mariano, C.S.F. \& Majer, J.D. (org.), As formigas Poneromorfas do Brasil. (pp. 447-462). Editus, Ilhéus-BA, Brasil.

Carnaval, A.C. \& Moritz, C. (2008). Historical climate modelling predicts patters of current biodiversity in the Brazilian Atlantic
Forest. Journal of Biogeography, 35: 187-1201. doi: 10.1111/j. 1365-2699.2007.01870.x

Colombo, A.F. \& Joly, C.A. (2010). Brazilian Atlantic Forest lato sensu: the most ancient Brazilian forest, and a biodiversity hotspot, is highly threatened by climate change. Brazilian Journal of Biology, 70: 697-708. doi: 10.1590/S151969842010000400002

Costa, L.P. (2003). The historical bridge between the Amazon and the Atlantic Forest of Brazil: a study of molecular phylogeography with small mammals. Journal of Biogeography, 30: 71-86. doi: 10.1046/j.1365-2699.2003.00792.x

Dejean, A., Labrière, N., Touchard, A., Petitclerc, F. \& Roux, O. (2014). Nesting habits shape feeding preferences and predatory behavior in an ant genus. Naturwissenschaften, 101: 323-330. doi: 10.1007/s00114-014-1159-1

Delabie, J.H.C., Jahyny, B., Nascimento, I.C., Mariano, C.S.F., Lacau, S., Campiolo, S., Philpott, S.M. \& Leponce, M. (2007). Contribution of cocoa plantations to the conservation of native ants (Insecta: Hymenoptera: Formicidae) with a special emphasis on the Atlantic Forest fauna of southern Bahia, Brazil. Biodiversity and Conservation, 16: 2359-2384. doi: doi: 10.1007/s10531-007-9190-6

Delabie, J.H.C., Mariano, C.S.F., Mendes, L.F., Pompolo, S.G. \& Fresneau, D. (2008). Problemas apontados por estudos morfológicos, ecológicos e citogenéticos no gênero Pachycondyla na região neotropical: o caso do complexo apicalis. In: Vilela, E.F., Santos, I.A., Schoereder, J.H., Serrão, J.E., Campos, L.A.O. \& Lino Neto, J. (Org.), Insetos Sociais da Biologia à Aplicação (pp. 197-222). Viçosa, Ed. UFV.

Feitosa, R. (2015). Lista das formigas poneromorfas do Brasil. In: Delabie, J.H.C., Feitosa, R., Serrão, J.E., Mariano, C.S.F. \& Majer, J. As formigas poneromorfas do Brasil (pp. 95-101). Editus, Ilhéus - BA, Brasil.

Ferreira, R.S., Poteaux, C., Delabie, J.H.C., Fresneau, D. \& Rybak, F. (2010). Stridulations reveal cryptic speciation in Neotropical sympatric ants. Plos One, 5: e15363. doi: 10.1371/journal.pone.0015363

Ferreira, C.R., Correia, M.E.F., Camara, R., Resende, A.S., Anjos, L.H.C. \& Pereira, M.G. (2018). Soil fauna changes across Atlantic Forest succession. Comunicata Scientiae, 9: 162-174. doi: 10.14295/CS.v9i2.2388

Folgarait, P. J. (1998). Ant biodiversity and its relationship to ecosystem functioning: a review. Biodiversity Conservation, 7: 1221-1244. doi: 10.1023/A:1008891901953

Guénard, B., Weiser, M.D. \& Dunn, R.R. (2012). Global models of ant diversity suggest regions where new discoveries are most likely are under disproportionate deforestation threat. PNAS, 109: 7368-7373. doi: 10.1073/pnas.1113867109

Instituto Brasileiro de geografia e Estatística (IBGE) (2004a). Mapa de Biomas do Brasil, Primeira Aproximação. Available 
online at http://www.ibge.gov.br (accessed date: December 2018).

Instituto Brasileiro de geografia e Estatística (IBGE) (2004b). Mapa de Vegetação do Brasil, Terceira Edição. Available online at http://www.ibge.gov.br (accessed date: December 2018).

Instituto Nacional de Pesquisas Espaciais (INPE) (2018). Available online at http://www.inpe.br (accessed date: AugustSeptember 2018).

Joly, C.A., Aidar, M.P.M., Klink, C.A., MCgrath, D.G., Moreira, A.G., Moutinho, P., Nepstad, D.C., Oliveira, A.A., Pott, A., Rodal, M.J.N. \& Sampaio, E.V.S.B. (1999). Evolution of the Brazilian phytogeography classification systems: implications for biodiversity conservation. Ciência e Cultura, 51: 331-348.

Jones, C.G., Lawton, J.H. \& Shachak, M. (1997). Positive and negative efects of organisms as physical ecosystem engineers. Ecology, 78: 1946-1957. doi: 10.2307/2265935

Klimes, P., Idigel, C., Rimandai, M., Fayle, T.M., Janda, M., Weiblen, G.D. \& Novotny, V. (2012). Why are there more arboreal ant species in primary than in secondary tropical forests? Journal of Animal Ecology, 81: 1103-1112. doi: $10.1111 / j .1365-2656.2012 .02002 . x$

Lattke, J.E. (2003). Subfamília Ponerinae. In: Fernandes, F. (ed). Introduccion a las Hormigas de la Region Neotropical (pp. 261-276). Instituto de Investigación de Recursos Biológicos Alexander von Humboldt, Bogotá, Colômbia. XXVI.

Lattke, J.E. (2015). Estado da arte sobre a taxonomia e filogenia de Ponerinae do Brasil. In: Delabie, J.H.C., Feitosa, R., Serrão, J.E., Mariano, C.S.F. \& Majer, J. As formigas poneromorfas do Brasil (pp. 55-73). Editus, Ilhéus - BA, Brasil.

Mackay, W.P. \& Mackay, E.E. (2010). The Systematics and Biology of the New World Ants of the Genus Pachycondyla (Hym.: Formicidae). Edwin Mellon Press, Lewiston, 2010.

Mittermeier, R.A., Gil, R.P., Hoffman, M., Pilgrim, J., Brooks, T., Mittermeier, C.G., Lamoreux, J. \& Fonseca, G.A.B. (2005). Hotspots Revisited: Earth's Biologically Richest and Most Endangered Terrestrial Ecoregions, 2. ed. University of Chicago Press, Boston.

Moreau, C.S., Bell, C.D., Vila, R., Archibald, S.B. \& Pierce, N.E. (2006). Phylogeny of the ants: diversification in the age of angiosperms. Science, 312: 101-104. doi: 10.1126/ science. 1124891

Morellato, L.P.C. \& Haddad, C.F.B. (2000). Introduction: The Brazilian Atlantic Forest. Biotropica, 32(4b): 786-792. doi: 10.1111/j.1744-7429.2000.tb00618.x

Ministério do Meio Ambiente (MMA) (2018). Available online at https://www.mma.gov.br (accessed date: AugustSeptember 2018).

Myers, N., Mittermeier, R.A., Mittermeier, C.G., Fonseca, G.A.B. \& Kent, J. (2000). Biodiversity hotspots for conservation priorities. Nature, 403: 853-858. doi: 10.1038/35002501
Papes, M. \& Gaubert, P. (2007). Modelling ecological niches from low numbers of occurrences: assessment of the conservation status of poorly known viverrids (Mammalia, Carnivora) across two continents. Diversity and Distributions, 13: 890902. doi: 10.1111/j.1472-4642.2007.00392.x

Pearson, R.G. \& Dawson, T.E. (2003). Predicting the impacts of climate change on the distribution of species: are bioclimate envelope models useful? Global Ecology and Biogeography, 12: 361-371. doi: 10.1046/j.1466-822X.2003.00042.x

Pereira, A.B. (2009). Mata Atlântica: Uma abordagem geográfica. Nucleus, 6: 27-52. doi: 10.3738/1982.2278.152

Peres, E.A., Pinto-da-Rocha, R., Lohmann, L.G., Michelangeli, F.A., Miyaki, C.Y., Carnaval, A. C. (2020). Patterns of Species and Lineage Diversity in the Atlantic Rainforest of Brazil. In: Rull V., Carnaval A. (eds) Neotropical Diversification: Patterns and Processes. Fascinating Life Sciences. Springer, Cham. doi: 10.1007/978-3-030-31167-416

Pires, A.P.F., Rezende, C.L., Assad, E.D., Loyola, R. \& Scarano, F.R. (2017). Forest restoration can increase the Rio Doce watershed resilience. Perspectives in Ecology and Conservation, 15: 187-193. doi: 10.1016/j.pecon.2017.08.003

R Development Core Team (2018). R: A language and environment for statistical computing. R Foundation for Statistical Computing, Vienna, Austria. Available in: http:// www.project.org/

Ribas, C.R., Schmidt, F.A., Solar, R.R.C., Campos, R.B.F., Valentim, C.L. \& Schoereder, J. H. (2012). Ants as indicators in Brazil: A review with suggestions to improve the use of ants in environmental monitoring programs. Restoration Ecology, 20: 712-720. doi: 10.1111/j.1526-100X.2011.00831.x

Ribeiro, M.C., Metzger, J.P., Martensen, A.C., Ponzoni, F.J. \& Hirota, M.M. (2009). The Brazilian Atlantic Forest: How much is left, and how is the remaining forest distributed? Implications for conservation. Biological Conservation, 142: 1141-1153. doi: 10.1016/j.biocon.2009.02.021

Santos, M., Louzada, J.N.C., Dias, N., Zanetti. R., Delabie, J.H.C. \& Nascimento, I.C. (2006). Riqueza de formigas (Hymenoptera, Formicidae) da serapilheira em fragmentos de floresta semidecídua da Mata Attântica na região do Alto do Rio Grande, MG, Brasil. Iheringia, Sér. Zool., Porto Alegre 96: 95-101. doi: 10.1590/S0073-47212006000100017

Schmidt, F.A., Ribas, C.R. \& Schoereder, J.H. (2013). How predictable is the response of ant assemblages to natural forest recovery? Implications of their use as bioindicators. Ecological Indicators, 24: 158-166. doi: 10.1016/j.ecolind. 2012.05.031

Schmidt, C.A. \& Shattuck, S.O. (2014). The higher classification of the ant subfamily Ponerinae (Hymenoptera: Formicidae), with a review of ponerine ecology and behavior. Zootaxa. 3817: 1-242. doi: 10.11646/zootaxa.3817.1.1 
Sigrist, M.S. \& Carvalho, C.J.B. (2008). Detection of areas of endemism on two spatial scales using Parsimony Analysis of Endemicity (PAE): The Neotropical region and the Atlantic Forest. Biota Neotropica, 8: 33-42. doi: 10.1590/S167606032008000400002

Silva, J.M.C., Souza, M.C. \& Castelletti, C.H.M. (2004). Areas of endemism for passerine birds in the Atlantic forest, South America. Global Ecology and Biogeography, 13: 8592. doi: 10.1111/j.1466-882X.2004.00077.x

Silva, R.R., Feitosa, R.M.S. \& Eberhard, F. (2007). Reduced ant diversity along a habitat regeneration gradient in the southern Brazilian Atlantic Forest. Forest Ecology and Management, 240: 61-69. doi: 10.1016/j.foreco.2006.12.002
SOS Mata Atlântica (2018). Available online at https:// www.sosma.org.br/wp-content/uploads/2019/05/Atlas-mataatlantica_17-18.pdf (accessed date: December 2018).

Tabarelli, M., Aguiar, A.V., Ribeiro, M.C., Metzger, J.P. \& Peres, C.P. (2010). Prospects for biodiversity conservation in the Atlantic Forest: Lessons from aging human-modified landscapes. Biological Conservation, 143: 2328-2340. doi: 10.1016/j.biocon.2010.02.005

Wild, A.L. 2005. Taxonomic revision of the Pachycondyla apicalis species complex (Hymenoptera: Formicidae). Zootaxa, 834: 1-25. doi: 10.11646/zootaxa.834.1.1

\section{Appendix}

References corresponding to the codes of the Table 5.

1. CPDC

2. Antmaps/Antweb

3. Araújo, E.S., Koch, E.B.A., Delabie, J.H.C., Zeppelini, D., Darocha, W.D., Castaño-Meneses, G. \& Mariano, C.S.F. (2019). Diversity of commensals within nests of ants of the genus Neoponera (Hymenoptera: Formicidae: Ponerinae) in Bahia, Brazil. Annales de la Société entomologique de France, 55 (4): 291-299. doi: 10.1080/00379271.2019.1629837

4. Campiolo, S. \& Delabie, J. H. C. (2000). Caractérisation de la myrmécofaune de la litière de la Forêt Atlantique du sud de Bahia - Brésil. Actes des Colloques Insectes Sociaux. 13: 65-70.

5. Cobb, M., Watkins, K., Silva, E. N., Nascimento, I. C. \& Delabie, J. H. C.(2006). An exploratory study on the use of bamboo pieces for trapping entire colonies of arboreal ants. Sociobiology 47 (1): 215-223.

6. Conceição, E. S., Delabie, J. H. C., Costa Neto, A. O., Moura, J. I. L. (2009). Atividade de formigas nas inflorescências do coqueiro no sudeste baiano, com enfoque sobre o período entre a antese e a formação do fruto. Agrotrópica 21(2): 113-122.

7. Conceição, E.S., Della Lucia, T.M.C., Costa-Neto, A.O., Araújo, E.S., Koch, E.B.A. \& Delabie, J.H.C. (2019). Ant community evolution according aging in Brazilian cocoa tree plantations. Sociobiology, 66(1): 33-43. Doi:10.13102/sociobiology.v66i1.2705

8. DaRocha, W.D., Ribeiro, S.P., Neves, F.S., Fernandes, G.W., Leponce, M. \& Delabie, J.H.C. (2015). How does bromeliad distribution structure the arboreal ant assemblage (Hymenoptera: Formicidae) on a single tree in a Brazilian Atlantic forest agroecosystem? Myrmecological News, 21: 83-92. ISSN 1994-4136 (print), ISSN 1997-3500 (online)

9. Delabie, J.H.C. \& Fowler, H.G. (1995). Soil and litter cryptic ant assemblages of Bahian cocoa plantations, Pedobiologia, 39: 423-433.

10. Delabie, J.H.C., Godé, L., Nascimento, I.C., Santos, J.R.M., Carmo, A.F.R., Mariano, C.S.F. \& Souza, P.R. (2015). Formigas (Hymenoptera) da Reserva de Pedra Talhada. In: Studer, A., Nusbaumer, L. \& Spichiger, R. (ed.). Biodiversidade da Reserva Biológica de Pedra Talhada (Alagoas, Pernambuco - Brasil). Boissiera 68: 277-288. ISBN 978-2-8277-0084-4, ISSN 0373-2975.

11. Delabie, J.H.C., Lacau, S., Nascimento, I.C., Casimiro, A.B. \& Cazorla, I.M. (1997). Communauté des fourmis des souches d'arbres morts dans trois réserves de la forêt Atlantique brésilienne (Hymenoptera, Formicidae). Ecologia Austral, 1997, 7: 95-103.

12. D’Ettorre, P., Kellner, K, Delabie, J.H.C. \& Heinze, J. (2005). Number of queens in founding associations of the ponerine ant Pachycondyla villosa. Insectes Sociaux 52: 327-332. Doi:10.1007/s00040-005-0815-z

13. Fernandes, I.O., Oliveira, M.L. \& Delabie, J.H.C. (2014). Description of two new species in the Neotropical Pachycondyla foetida complex (Hymenoptera: Formicidae: Ponerinae) and taxonomic notes on the genus. Myrmecological News, 19: 133-163. ISSN 1994-4136 (print), ISSN 1997-3500 (online).

14. Fowler, H.G. \& Delabie, J. H. C. (1995). Resource partitioning among epigaeic and hypogaeic ants (Hymenoptera: Formicidae) of a Brazilian cocoa plantation. Ecologia Austral, 5: 117-124.

15. Freitas, J.M.S., Delabie, J.H.C. \& Lacau, S. (2014). Composition and diversity of ant species into leaf litter of two fragments of a semideciduous seasonal forest in the Atlantic forest biome in Barra do Choça, Bahia, Brazil. Sociobiology 61(1): 9-20. doi:10.13102/sociobiology. v61i1.9-20

16. Gomes E.C.F., Ribeiro, G. T., Souza, T.M.S. \& Sousa-Souto, L. (2014). Ant assemblages (Hymenoptera: Formicidae) in three different stages of forest regeneration in a fragment of Atlantic Forest in Sergipe, Brazil. Sociobiology, 61(3): 250-257. Doi:10.13102/sociobiology.v61i3.250-257 
17. Heinze, J., Trunzer, B., Hölldobler, B. \& Delabie, J. H. C. (2001). Reproductive skew and queen relatedness in an ant with primary polygyny. Insectes Sociaux, 48: 149-153. Doi:10.1007/PL00001758

18. Kempf, W.W. (1972). Catálogo abreviado das formigas da região Neotropical (Hym. Formicidae) Studia Entomologica 15(1-4).

19. Koch, E. B. A, Santos, J. R. M., Nascimento, I. C. \& Delabie, J. H. C. (2019). Comparative evaluation of taxonomic and functional diversities of leaf-litter ants of the Brazilian Atlantic Forest. Turkish Journal of Zoology, 43: 437-456. Doi:10.3906/zoo-1811-7

20. Lucas, C., Fresneau, D., Kolmer, K., Heinze, J., Delabie, J. H. C. \& Pho, D. B. (2002). A mutidisciplinary approach to discrimining different taxa in the species complex Pachycondyla villosa (Formicidae). Biological Journal of the Linnean Society, 75: 249-259. Doi:10.1046/ j.1095-8312.2002.00017.x

21. Mackay, W.P. \& Mackay, E.E. (2010). The Systematics and Biology of the New World Ants of the Genus Pachycondyla (Hymenoptera: Formicidae). Edwin Mellon Press, Lewiston.

22. Majer, J.D., Delabie, J.H.C. \& Mckenzie, N. L. (1997). Ant litter fauna of forest edge and adjacent grassland in the Atlantic rain forest region of Bahia, Brazil. Insectes Sociaux, 44: 255-266. Doi:10.1007/s000400050046

23. Majer, J.D. \& Delabie, J.H.C. (1999). Impact of tree isolation on arboreal and ground ant communities in cleared pasture in the Atlantic rain forest region of Bahia, Brazil. Insectes Sociaux, 46 (3): 281-290. doi:10.1007/s000400050147

24. Mariano, C.S.F., Pompolo, S.G., Borges, D.S. \& Delabie, J.H.C. (2006). Are the Neotropical ants Pachycondyla crenata (Roger) and Pachycondyla mesonotalis (Santschi) (Formicidae, Ponerinae) good species? A cytogenetic approach. Myrmecologische Nachrichten/ Myrmecological News 8 (Stefan Schoedl Memorial Volume): 277-280.

25. Mariano, C.S.F., POMPOLO, S.G., Silva, J.G. \& Delabie, J.H.C. (2012). Contribution of cytogenetics to the debate on the paraphyly of Pachycondyla spp. (Hymenoptera; Formicidae; Ponerinae). Psyche, vol. 2012, Article ID 973897, 9 pages. doi:10.1155/2012/973897.

26. Melo, T.S., Peres, M.C.L., Chavari, J L., Brescovit, A.D. \& Delabie, J.H.C. (2014). Ants (Formicidae) and spiders (Araneae) listed from the metropolitan region of Salvador, Brazil. Check List, 10(2): 355-365. Doi:10.15560/10.2.355

27. Oliveira, G. V., Corrêa, M. M., Góes, I. M. A., Machado, A. F., Sá-Neto, R. J. \& Delabie, J. H. C. (2015). Interactions between Cecropia (Urticaceae) and ants (Hymenoptera: Formicidae) along a longitudinal east-west transect in the Brazilian Northeast. Annales de la Société Entomologique de France, 51(2): 153-160. doi: 10.1080/00379271.2015.1061231.

28. Peres, M.C.L., Benati, K., Dias, M.A., Uzel-Sena, D., Andrade, A.R.S., Melo, T.S., Guimarães, M.V.A. \& Delabie, J.H.C. (2017). Are leaf-litter ants (Formicidae) distributed differentiatedly between inner zones of natural treefall gaps? International Journal of Research Studies in Biosciences, 5(7): 60-68. Doi:10.20431/2349-0365.0507009

29. Pessoa, W.P.B., Silva, L.C.C., Dias, L.O., Delabie, J.H.C., Costa, H. \& Romano, C.C. (2016). Analysis of protein composition and bioactivity of Neoponera villosa venom (Hymenoptera: Formicidae). International Journal of Molecular Sciences, 17: 513. doi: 10.3390/ijms17040513

30. Resende, J. J., Santos, G. M. M., Nascimento, I. C., Delabie J. H. C. \& Silva, E. M. (2011). Communities of ants (Hymenoptera Formicidae) in different Atlantic Rain Forest phytophysionomies. Sociobiology, 58(3): 779-799.

31. Resende, J. J., Peixoto, P. E. C., Silva, E. N., Delabie, J. H. C. \& Santos, G. M. M. (2013). Arboreal ant assemblages respond differently to food source and vegetation physiognomies: a study in the Brazilian Atlantic Rain Forest. Sociobiology 60 (2): 174-182. doi: 10.13102/sociobiology

32. Santana, F. D., Cazetta, E. \& Delabie, J. H. C. (2013). Interactions between ants and non-myrmecochorous diaspores in a tropical wet forest in southern Bahia, Brazil. Journal of Tropical Ecology, 21(1): 71-80. doi: 10.1017/S0266467412000715.

33. Santos, M.P.C.J., Carrano-Moreira, A.F. \& Torres, J.B. (2012). Diversity of soil ant (Hymenoptera: Formicidae) in dense Atlantic Forest and sugarcane plantations in the County of Igarassu-PE. Revista Brasileira de Ciências Agrárias, 7(4): 648-656. doi: 10.5039/agraria.v7i4a1927

34. Santos, R.J., Koch, E. B. A., Machado, C., Leite, P., Porto, T. J. \& Delabie, J. H. C. (2017). An assessment of leaf-litter and epigaeic ants (Hymenoptera: Formicidae) living in different landscapes of the Atlantic Forest Biome in the State of Bahia, Brazil. Journal of Insect Biodiversity, 5(19): 1-19. doi: 10.12976/jib/2017.5.19

35. Santos, R.P., Mariano, C.S.F., Delabie, J.H.C., Costa, M.A., Lima, K.M., Pompolo, S.G., Fernandes, I.O., Miranda, E. A., Carvalho, A.F. \& Silva, J.G. (2018). Genetic characterization of some Neoponera (Hymenoptera: Formicidae) populations within the foetida species complex. Journal of Insect Science, 18 (4): 11; 1-7. doi: 10.1093/jisesa/iey079

36. Silva, R. R. \& C. Brandão, R. F. (2014). Ecosystem-Wide Morphological Structure of Leaf-Litter Ant Communities along a Tropical Latitudinal Gradient. PlosOne 9(3): e93049. doi: 10.1371/journal.pone.0093049

37. Tentschert, J., Kolmer, K., Hölldobler, B., Bestmann, H. J., Delabie, J. H. C. \& Heinze, J. (2001). Chemical profiles, division of labor and social status in Pachycondyla queens (Hymenoptera: Formicidae). Naturwissenschaften, 88: 175-178. doi: 10.1007/s001140100218

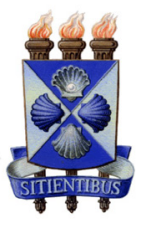

